\title{
Salinity effects on protein content, lipid peroxidation, pigments, and proline in Paulownia imperialis (Siebold \& Zuccarini) and Paulownia fortunei (Seemann \& Hemsley) grown in vitro
}

\author{
Gloria Irma Ayala-Astorga ${ }^{1} \cdot$ Lilia Alcaraz-Meléndez $^{2} \square$ \\ 1 Departamento de Investigación Científica y Tecnológica, Universidad de Sonora, Hermosillo, Sonora, México \\ 2 Centro de Investigaciones Biológicas del Noroeste, La Paz, Baja California Sur, México
}

$\triangle$ Corresponding author: lalcaraz04@cibnor.mx

Received February 21, 2010 / Accepted June 24, 2010

Published online: September 15, 2010

(C) 2010 by Pontificia Universidad Católica de Valparaíso, Chile

\begin{abstract}
We evaluated the effects of saline stress on soluble proteins, lipid peroxidation (TBAR), chlorophyll $a$, chlorophyll $b, \beta$-carotene, violaxanthin, and proline in Paulownia imperialis and Paulownia fortunei plants grown in vitro. When the propagated plants reached a determined size, they were transferred aseptically to WPM culture medium containing different sodium chloride concentrations $(0,20,40$, 60,80 , and $160 \mathrm{mM}$ ) and were sampled at 15 and 30 days. Proline content was determined at 30 days after transfer only. Protein concentration significantly decreased with the highest salt levels in $P$. imperialis compared to controls in which no sodium chloride was added. In both $P$. imperialis and $P$. fortunei, lipid peroxidation significantly increased at 15 days but decreased at 30 days. Chlorophyll a, chlorophyll $b, \beta$-carotene, and violaxanthin significantly decreased with exposure to higher sodium chloride concentrations at 15 and 30 days in both species. Proline content in $P$. imperialis significantly increased in plants grown in 20 and $40 \mathrm{mM}$ of sodium chloride and decreased in higher sodium chloride concentrations. In $P$. fortunei, this measure significantly decreased proline content at all salt concentrations in plants exposed to all levels of sodium chloride compared to controls. Our results show that $P$. imperialis is more tolerant to salt stress at the salinity conditions tested.
\end{abstract}

Keywords: Paulownia fortunei, Paulownia imperialis, pigments, proline, proteins, salinity, TBARS, tissue culture

\section{INTRODUCTION}

One third of the world's agricultural land is damaged, and approximately $5 \%$ of 1.5 Bha of cultivated land is affected by salt (Tabatabaei, 2006). Environmental degradation, mainly soil pollution and erosion, desertification, declining biodiversity, and overuse of agrochemicals cause biotic and abiotic stress in plants (Shao and Chu, 2005); among those stresses that limit plant growth and development, drought is a major factor and is closely related to salt stress (Song et al. 2008). Abiotic stress, 
particularly salinity and drought are major stresses that cause crop losses worldwide (Vinocur and Altman, 2005). Plant responses to salt and water stress involve many macromolecules and small compounds, such as proline (Shao et al. 2006). Salinity in agricultural land limits crop productivity due to irrigation practices with bad quality water (Chinnusamy et al. 2005); sodium chloride is the most abundant salt that contributes to soil salinity (Koca et al. 2007). High salinity causes severe damage to plants, including growth inhibition, impaired metabolism, necrosis, and loss of production and quality (Sivritepe and Eris, 1999). In addition to the toxicity caused by ions, salinity and osmotic stress cause an imbalance of nutrients in plants (Cavagnaro et al. 2006; Song et al. 2006). The imbalance caused by salinity affects the nutrients involved in protein synthesis and those involved in photosynthesis, which can lead to inhibition of these processes (Vieira-Santos et al. 2001), as well as to the degradation of pigments chlorophyll $a$ and $b$ (Di Martino et al. 2003).

Research to improve salt tolerance in plants is mainly focused on biochemical and physiological aspects. The genes responsible for salt tolerance in some species have been identified (Schleiff, 2008), but stress might occur as a complex mechanism of several interacting environmental factors that cause variations in plant phenotypes, as plants respond to complex growth conditions (Shao et al. 2007a). Salt stress causes the plants to suffer dehydration, which is one of the abiotic stresses in plants.

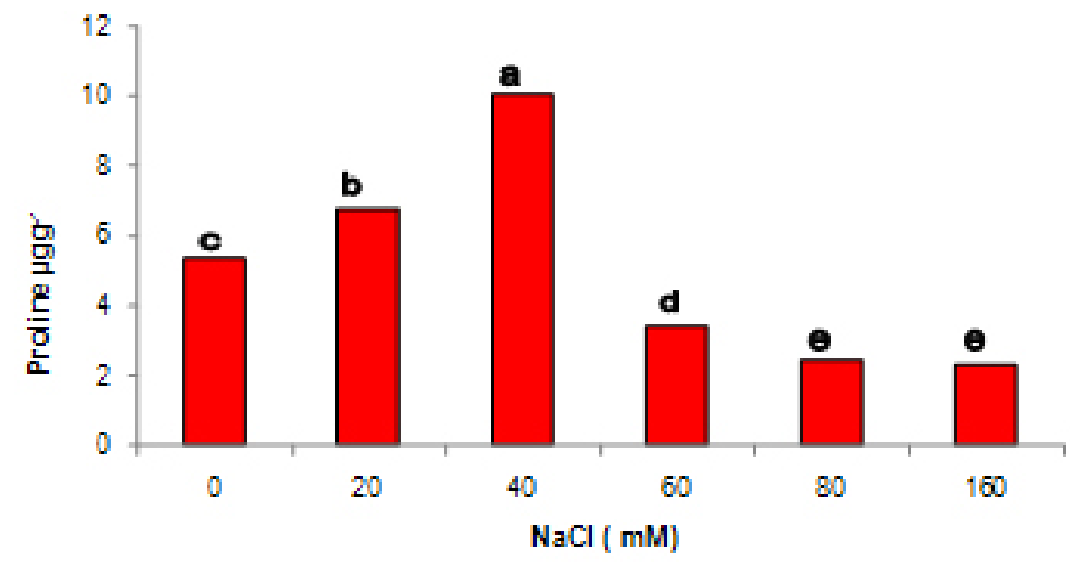

Fig.1 Effect of sodium chloride (mM) on proline $(\mu \mathrm{g} / \mathrm{g})$ in $P$. imperialis at 30 days. Values not associated with the same letter are significantly different $(P<0.05)$.

It is known that osmotic stress induces oxidative damage, reducing biosynthesis of compound osmoprotectors; basically plants record their environment and respond with resistance or adaptation mechanisms (Shao et al. 2007b; Shao et al. 2008). On the other hand, plant stress mechanisms are very different depending on the degree of stress tolerance, growth, and different development stages, evolution in time, materials and experimental plots, which increase their complexity (Shao et al. 2005a). To protect and preserve osmotic stability, cells accumulate proline that is probably the most widely osmolyte found in plants and other organisms (Bartels and Sunkar, 2005). Proline is a compound that tends to accumulate in response to metabolic salt stress (Cushman, 2001); it is thus important in the osmotic adjustment in plants under 
stress (Di Martino et al. 2003; Mademba et al. 2003) and serves as an osmoprotectant (Benavides, 2002; Wanichananan et al. 2003). It is understood that proline is a consistent and compatible solute that does not inhibit enzymatic activities (Rathinasabapathi, 2000) at high concentrations, and facilitates biochemical reactions (Tester and Davenport, 2003). Cavagnaro et al. 2006 have suggested that culture in vitro is an appropriate system for studies on salinity in plants because it easily recapitulates the results found in the field and in greenhouses where environmental conditions are controlled. Plant cell and tissue culture methods could be useful in studying salinity tolerance mechanisms in plants and their effects on crop production when they are not evidently known (Akinci and Simsek, 2004).

Paulownia trees are native to China and have spread to other countries, such as Korea, Japan, Australia, and the United States. They can reach up to 30 meters at maturity (Bonner, 1995), have a significant economical value because they produce very high quality wood (Bergmann, 1998), and they can be used in paper pulp manufacture. These characteristics make the tree suitable for its use in furniture and poles. Even though the wood is light, it can be processed cost-effectively, as it does not contain resins or oils. In addition, it can be used as fodder and is economically important when used in intercropping systems (Jianbo, 2006). Paulownia imperialis (syn. P. tomentosa) has become very important in the United States after its naturalization over 150 years ago (Bergmann, 2003). Paulownia fortunei is a potential agroforestry species (Muthuri et al. 2005) that can reach a height of $8 \mathrm{~m}$ in five years; its timber is used for microclimatic improvement, forestation, and remediation.

The purpose of this investigation was to determine the sodium chloride tolerance of $P$. imperialis and $P$. fortunei based on analyses of soluble proteins, lipid peroxidation, chlorophyll $a$, chlorophyll $b, \beta$-carotene violaxanthin, and proline content in plants grown in vitro.

\section{MATERIALS AND METHODS}

\section{Tissue culture}

Culture WPM (Woody Plant Medium) (Trigiano and Gray, 2000) was prepared with $3 \%$ sucrose, and $\mathrm{pH}$ was adjusted to 5.8 . Agar (0.8\%) was added (Difco Bacto agar), medium was placed in $20 \mathrm{ml}$ vessels, and the vessels and medium were sterilised at $121^{\circ} \mathrm{C}$ and $15 \mathrm{lb}$ of pressure for $15 \mathrm{~min}$.

\section{Plant growth}

The seeds of Paulownia imperialis and Paulownia fortunei (from Sandeman Seeds, France) were disinfected with $95 \%$ ethyl alcohol (v/v) for $5 \mathrm{sec}$ and $20 \% \mathrm{NaOCl}$ for 5 min. Seeds were then rinsed four times in sterile distilled water. The seeds were inoculated aseptically in a laminar flow chamber (Edge Gard Hood). The cultures were incubated in a growth chamber at $25 \pm 2^{\circ} \mathrm{C}$ at a relative humidity of $70 \%$ under 16 hrs of light.

After two months under these conditions, the plants were transferred aseptically to a new culture medium containing WPM with sodium chloride at concentrations of 0,20 , 
$40,60,80$, and $160 \mathrm{mM}$. Ten vessels were prepared for each treatment, one plant per vessel and placed in the controlled incubation conditions mentioned above.

\section{Protein determination}

Protein determination was made according to the Bradford method (Bradford, 1976) and using a standard curve prepared with bovine serum albumin. Briefly, Coomassie blue, in response to protein concentration, reacts with basic amino acid residues, especially arginine. When the plants had been treated with salt conditions for 15 and 30 days, $100 \mathrm{mg}$ of the dried aerial portion was placed in a test tube with $2 \mathrm{ml}$ of 50 $\mathrm{mM}$ potassium phosphate buffer at $\mathrm{pH}$ 7.0. Plant tissues were centrifuged at 7000 $12000 \mathrm{rpm}$. The supernatant was recovered and centrifuged at $3000 \mathrm{rpm}$ for $15 \mathrm{~min}$ at $4^{\circ} \mathrm{C}$. Samples were diluted $1: 100$ and read in triplicate in a spectrophotometer at 595 $\mathrm{nm}$.

\section{Lipid peroxidation (TBARS) determination}

For each sodium chloride concentration, the aerial part of three plants was cut and dried at 15 and 30 days to quantify malondialdehyde (MDA) production. Lipid hydroperoxides and aldehydes resulting from peroxidation of the cell membrane react with thiobarbituric acid (TBA) to form MDA, which is a crystalline pink pigment with absorption from 525 to $535 \mathrm{~nm}$ (Persky et al. 2000). To assay MDA production, $2 \mathrm{ml}$ of $0.9 \%$ saline solution at $\mathrm{pH} 7$ was added to tubes. The tubes were kept on ice, and $100 \mathrm{mg}$ of dried tissue was added. The tissues were centrifuged at a speed from 7000 to $12000 \mathrm{rpm}$. Then, $250 \mu \mathrm{l}$ of each supernatant was added to $1.5 \mathrm{ml}$ Eppendorf tubes. All samples were analysed in triplicate. Samples and standards were incubated at $37^{\circ} \mathrm{C}$ in a water bath for fifteen minutes. The tubes were then removed and placed in an ice bath to stop the reaction. Five hundred microlitres of TBA (thiobarbituric acid) solution were added to each tube (Sigma T5500). Samples were kept under constant stirring with a vortex. The tubes were placed in a shaking water bath at $90^{\circ} \mathrm{C}$ for ten min. The tubes were kept closed and placed in an ice bath until cool and then centrifuged at $3000 \mathrm{rpm}$ for $10 \mathrm{~min}$ at $4^{\circ} \mathrm{C}$. Each supernatant $(1.5 \mathrm{ml})$ was transferred to a plastic cell for analysis in a spectrophotometer (Jenway $6505 \mathrm{UV} / \mathrm{Vis}$ ) at $532 \mathrm{~nm}$ (Persky et al. 2000).

Table 1. Effect of sodium chloride (mM) on protein levels $(\mathrm{mg} / \mathrm{l})$ in Paulownia imperialis and Paulownia fortunei at $\mathbf{1 5}$ and $\mathbf{3 0}$ days. Letters denote a statistically significant difference $(P<0.05)$ in levels of proteins at 15 and 30 days. Values not associated with the same letter are significantly different $(P<0.05)$.

\begin{tabular}{ccccc}
\hline & \multicolumn{2}{c}{ Paulownia imperialis } & \multicolumn{2}{c}{ Paulownia fortunei } \\
\hline $\begin{array}{c}\mathrm{NaCl} \\
(\mathrm{mM})\end{array}$ & \multicolumn{2}{c}{ Days } & \multicolumn{2}{c}{ Days } \\
& 15 & 30 & 15 & 30 \\
\hline 0 & $1.075 \pm 0 \mathrm{~b}$ & $0.109 \pm 0.01 \mathrm{~b}$ & $0.350 \pm 0 \mathrm{~b}$ & $0.109 \pm 0.01 \mathrm{c}$ \\
\hline 20 & $1.439 \pm 0 \mathrm{a}$ & $0.182 \pm 0 \mathrm{a}$ & $0.53 \pm 0.26 \mathrm{~b}$ & $0.076 \pm 0.01 \mathrm{~d}$ \\
\hline 0 & $1.196 \pm 0.2 \mathrm{~b}$ & $0.109 \pm 0.01 \mathrm{~b}$ & $1.196 \pm 0.21 \mathrm{c}$ & $0.134 \pm 0.01 \mathrm{c}$ \\
\hline 60 & $1.075 \pm 0 \mathrm{~b}$ & $0.096 \pm 0.02 \mathrm{bc}$ & $0.712 \pm 0 \mathrm{~b}$ & $0.114 \pm 0.01 \mathrm{c}$ \\
80 & $1.075 \pm 0 \mathrm{~b}$ & $0.076 \pm 0.01 \mathrm{c}$ & $2.16 \pm 0 \mathrm{a}$ & $0.153 \pm 0 \mathrm{abc}$ \\
\hline 160 & $0.591 \pm 0.2 \mathrm{c}$ & $0.172 \pm 0.01 \mathrm{a}$ & $1.80 \pm 0.51 \mathrm{a}$ & $0.172 \pm 0.01 \mathrm{a}$ \\
\hline
\end{tabular}




\section{Pigment determination}

The pigments were analysed using HPLC (High Performance Liquid Chromatography). Samples were collected from the aerial parts of three plants grown in varying concentrations of sodium chloride at 15 and 30 days of incubation. Samples of the control plants for both Paulownia species were also collected at these times. For pigment extraction, 1-3 mg of freeze-dried material from the aerial part of each plant was extracted with $1 \mathrm{ml}$ acetone and weighed. The samples, covered with aluminium foil to protect them from light, were incubated for $24 \mathrm{hrs}$ at $-20^{\circ} \mathrm{C}$. Thawed samples were centrifuged at $4000 \mathrm{rpm}$ for $15 \mathrm{~min}$ at $5^{\circ} \mathrm{C}$. The extract was filtered through a $0.45 \mu \mathrm{m}$ fibreglass membrane. The filtrate was recovered in Eppendorf vials and stored at $-20^{\circ} \mathrm{C}$. Then $20 \mu \mathrm{l}$ of each sample was injected into the high performance liquid chromatographer (HPLC Model 1100, Hewlett Packard, Palo Alto, C.A.).

For pigment separation, we used the method described by Vidussi et al. 1996, using a mobile phase and combining two solutions. The first solution (A) was a mixture of methanol and $1 \mathrm{~N}$ ammonium acetate at a 70:30 ratio $(\mathrm{v} / \mathrm{v})$, and the second solution (B) was $100 \%$ HPLC grade methanol. The stationary phase used was a Hypersil C8 column that was $10 \mathrm{~cm}$ in length, $0.45 \mathrm{~cm}$ in diameter, and filled with $5 \mu \mathrm{m}$ particles of silica. The detector used was an array of diodes with a wavelength range of 190-900 $\mathrm{nm}$ and the capacity to determine five fixed wavelengths. Quantification was done by generating a standard curve with concentrations of $20,40,60,80$, and $100 \mathrm{ng} / \mathrm{ml}$ of each pigment. The pigments identified were chlorophyll $a$, chlorophyll $b, \beta$-carotene, and violaxanthin.

\section{Proline determination}

Proline content was analysed after the plants had grown for 30 days under the various salinity conditions. The proline analysis was conducted using HPLC (Varian, Palo Alto, CA. Model 5000), according to the technique described by Vázquez-Ortíz et al. (1995). Samples were prepared from the aerial parts of three plants for each sodium chloride treatment. Extracts for analyses were prepared by blending $1.0 \mathrm{~g}$ of the plant tissue with $2.0 \mathrm{ml}$ of trichloroacetic acid (TCA) (Sigma T6399) in a blender (VWR). The extracts were centrifuged and the supernatants were mixed with $0.4 \mathrm{M}$ of borate buffer solution and NBD-Cl (7-chloro-4-nitrobenzo 2 oxa-1,3-diazol-) $(2 \mathrm{mg} / \mathrm{ml}$ in methanol). Extracts were mixed and maintained at $60^{\circ} \mathrm{C}$ for $5 \mathrm{~min}$. Then the reaction was stopped by adding $50 \mu \mathrm{l}$ of $1 \mathrm{M} \mathrm{HCl}$ and cooled at $0^{\circ} \mathrm{C}$ for $30 \mathrm{~min}$. Ten microlitres of each sample were injected in the HPLC; the column used was a Lichrosor RP-18, 5 $\mu \mathrm{m}(30 \mathrm{~cm} \times 4.6 \mathrm{~mm}$ ID). The mobile phase (A) was prepared with $0.1 \mathrm{M}$ sodium acetate buffer, $\mathrm{pH} 7.2$, using methanol and tetrahydrofuran $(900: 95: 5 \mathrm{v} / \mathrm{v} / \mathrm{v})$ (Sigma Chemical Co.) as organic modifiers. The mobile phase solvent (B) was methanol (Merck). Solvents were filtered through $0.22 \mu \mathrm{m}$ filters (Millipore Corporation). Proline (Pierce Chemical Co.) was used to generate a standard curve. The flow was $1 \mathrm{ml} / \mathrm{min}$ from 25 to $29^{\circ} \mathrm{C}$, and the retention time for proline was $5 \mathrm{~min}$.

\section{Statistical analysis}

We used a completely randomised design with three replicates. To determine significant differences among treatments, we used the variance analysis of one of them. LSD was used to compare the mean values with a confidence level of $95 \%$. 
The results were statistically analysed using the StatGraphic Version 1.4 Plus program.

\section{RESULTS AND DISCUSSION}

\section{Protein determination}

Paulownia imperialis. Protein content was higher in plants grown in the lowest concentration of sodium chloride $(20 \mathrm{mM})$ (Table 1) at 15 days. Protein content was statistically similar in plants grown at concentrations of 40,60 , and $80 \mathrm{mM}$ of sodium chloride, and significantly decreased at the highest sodium chloride concentration $(160 \mathrm{mM})$. At 30 days, the protein content of the control plants and that of the plants grown with $40 \mathrm{mM}$ of sodium chloride did not show significant differences compared to that of the plants treated with $60 \mathrm{mM}$. Protein content significantly decreased in plants treated with $80 \mathrm{mM}$ of sodium chloride and increased in plants grown in 160 $\mathrm{mM}$. One characteristic of saline stress is the removal of potassium ions by plant roots, which causes a physiological imbalance because potassium is necessary for protein synthesis. Potassium loss causes diminished plant growth and development (Chen et al. 2007). If the stress is prolonged, it could affect protein synthesis and eventually cause it to decline (Caplan et al. 1990).

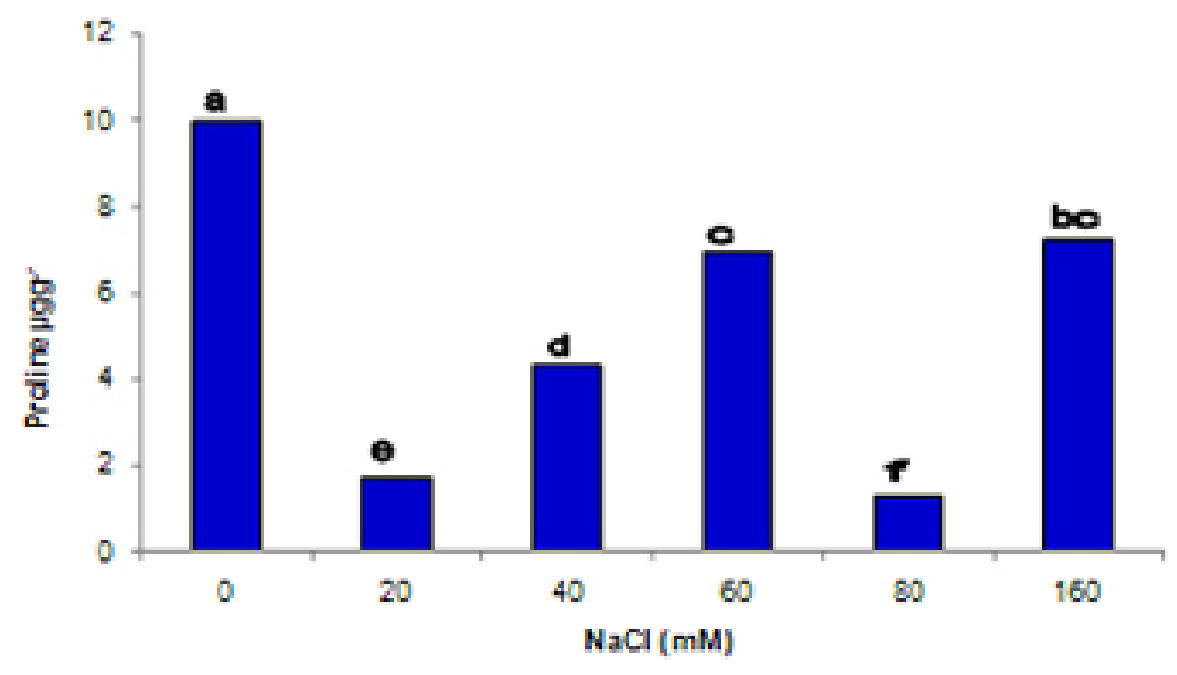

Fig. 2 Effect of sodium chloride $(\mathrm{mM})$ on proline $(\mu \mathrm{g} / \mathrm{g})$ in $P$. fortunei at 30 days. Values not associated with the same letter are significantly different $(P<0.05)$.

Paulownia fortunei. Plants grown in higher salinity levels (80 and $160 \mathrm{mM}$ of sodium chloride) showed significantly higher levels of soluble protein at 15 days (Table 1), while plants grown at lower sodium chloride levels showed statistically similar concentrations of soluble proteins compared with those of the control plants. At 30 days, the highest soluble protein concentration was observed in plants grown at higher sodium chloride levels $(160 \mathrm{mM})$. Protein content may have increased because 
plants have some tolerance level at these sodium chloride concentrations. The decrease in protein content is due to the effects of sodium chloride on protein synthesis (Omar et al. 1993). Furthermore, prolonged stress could affect protein synthesis and provoke its decline (Caplan et al. 1990). Protein content in Vignia unguiculata (L) Walp. Vita 5 was not affected compared to controls, while it significantly increased in the stems of plants grown with $100 \mathrm{mM}$ of sodium chloride (Franco et al. 1999). To survive under stress, plants accumulate proteins that protect cells from stress effects (Wang et al. 2003); we observed higher protein concentrations in $P$. imperialis than in $P$. fortunei. These results show that $P$. imperialis is more tolerant to salinity.

\section{Lipid peroxidation (TBARS)}

TBAR content was unstable in Paulownia imperialis plants grown in increased levels of sodium chloride at 15 days. Control plants and plants that were grown in $40 \mathrm{mM}$ of sodium chloride showed similar results (Table 2). Lipid peroxidation levels may indicate osmotic stress due to increased proline content (Figure 1). After 30 days, the control showed the highest value and lipid peroxidation decreased in plants grown in increasing sodium chloride concentrations. In two wheat cultivars (Sardari and Alvand), lipid peroxidation increased with 100, 150, and $200 \mathrm{mM}$ of sodium chloride in Alvand; however, in the Sardari cultivar lipid peroxidation increased with $50 \mathrm{mM} \mathrm{NaCl}$, decreased with $100 \mathrm{mM} \mathrm{NaCl}$, and remained unchanged with increasing salt level (Esfandiari et al. 2007).

In $P$. fortunei, TBAR content significantly declined in plants grown with increasing levels of sodium chloride. At $20 \mathrm{mM}$ of sodium chloride, the TBAR content did not vary with respect to the value obtained for the control plants at 15 days. At 30 days, TBAR content significantly increased in plants grown with $20 \mathrm{mM}$ of sodium chloride, and it significantly declined in plants grown at the other salinity levels (Table 2). These

Table 2. Effect of sodium chloride on lipid peroxidation (nmolTBARSmg/protein) in Paulownia imperialis and Paulownia fortunei at $\mathbf{1 5}$ and $\mathbf{3 0}$ days. Letters denote a statistically significant difference $(P<0.05)$ in levels of lipids peroxidation at 15 and 30 days. Values not associated with the same letter are significantly different $(P<0.05)$.

\begin{tabular}{|c|c|c|c|c|}
\hline \multirow[t]{3}{*}{$\begin{array}{l}\mathrm{NaCl} \\
(\mathrm{mM})\end{array}$} & $\begin{array}{l}\text { Paulownia } \\
\text { imperialis }\end{array}$ & & $\begin{array}{c}\text { Paulownia } \\
\text { fortunei }\end{array}$ & \\
\hline & Days & & Days & \\
\hline & 15 & 30 & 15 & 30 \\
\hline 0 & $359.7 \pm 34.1 \mathrm{c}$ & $9407.58 \pm 959.52 a$ & $5787.97 \pm 530.67 a$ & $20270.08 \pm 2380.7 b$ \\
\hline 20 & $924.25 \pm 69.49 b$ & $5676.98 \pm 660.18 b$ & $\begin{array}{l}4925.33 \pm \\
2197.92 a\end{array}$ & $\begin{array}{c}36674.24 \pm \\
7443.71 \mathrm{a}\end{array}$ \\
\hline 40 & $581.61 \pm 188.72 b c$ & $2830.83 \pm 1383.68 c$ & $\begin{array}{l}3497.01 \pm \\
652.73 a c\end{array}$ & $\begin{array}{l}7970.78 \pm \\
2735.98 \mathrm{~cd}\end{array}$ \\
\hline 60 & $3683.7 \pm 604.22 \mathrm{a}$ & $\begin{array}{l}3980.91 \pm \\
2408.76 \mathrm{bc}\end{array}$ & $2805.7 \pm 253 b$ & $\begin{array}{c}11957.89 \pm \\
2230.53 c\end{array}$ \\
\hline 80 & $1252.71 \pm 51.23 b$ & $\begin{array}{l}4209.09 \pm \\
1429.57 \mathrm{bc}\end{array}$ & $1163.58 \pm 78.88 c$ & $3688.68 \pm 587.05 d$ \\
\hline 160 & $3703.2 \pm 260.62 a$ & $2340.64 \pm 215.74 c$ & $1141.96 \pm 24.47 c$ & $3855.37 \pm 617.08 d$ \\
\hline
\end{tabular}


results are not consistent with experiments performed with onions (Allium cepa L.), where TBAR content increased with salinity (El-Baky et al. 2003), or in experiments with cowpea plants (Vigna unguiculata $(\mathrm{H})$ Walp), where an increase in TBAR content was noted in plants grown with $200 \mathrm{mM}$ of sodium chloride (Cavalcanti et al. 2004). In Carrizo citrange plants, lipid peroxidation increased with 30,60 , and $90 \mathrm{mM} \mathrm{NaCl}$ (Arbona et al. 2003).

\section{Pigment content quantitation}

$P$. imperialis. Higher salinity significantly reduced chlorophyll a content as observed at both sampling times (15 and 30 days) (Table 3 ). At 15 days, chlorophyll $b$ content in plants grown at 20 and $40 \mathrm{mM}$ of sodium chloride did not vary with respect to controls. High sodium chloride concentrations resulted in a significant decrease in chlorophyll $b$ (Table 3). At 30 days, chlorophyll $b$ significantly decreased with all the sodium chloride concentrations tested. Decreases in both pigments were reported by Di Martino et al. (2003) in spinach (Spinacia oleraceae) exposed to salinity stress.

$\beta$-carotene content significantly decreased in plants grown in high concentrations of Sodium chloride at day 15 (Table 3). However, after 30 days of growth in the lowest level of sodium chloride $(20 \mathrm{mM}), \beta$-carotene content was equal to that in control plants. $\beta$-carotene levels significantly decreased in plants grown with increasing levels of salinity.

At 15 and 30 days, violaxanthin content (Table 3) significantly decreased in all plants grown in salinity conditions compared with the control plants. In work done with the halophyte Atriplex centralasiatica with sodium chloride concentrations ranging from 0 to $400 \mathrm{mM}$, the content of chlorophyll $a+b$ and $\beta$-carotene remained unchanged at increased sodium chloride concentrations (Qiu et al. 2003).

$P$. fortunei. Table 4 shows that chlorophyll a content in control plants was similar to that in plants that were grown in 20,40 , and $60 \mathrm{mM}$ of sodium chloride at 15 sampling days. It significantly decreased with 80 and $160 \mathrm{mM}$ of sodium chloride at 15 days, while at 30 days, the pigment fell significantly in increased salinity.

Table 3. Effect of sodium chloride (mM) on pigments $(\mathrm{ng} / \mathrm{hg})$ in Paulownia imperialis at 15 and 30 days. Letters denote a statistically significant difference $(P<0.05)$ in levels of pigments at 15 and 30 days. Values not associated with the same letter are significantly different $(P<$ 0.05).

\begin{tabular}{ccccccccc}
\hline $\begin{array}{c}\text { NaCl } \\
(\mathbf{m M})\end{array}$ & \multicolumn{2}{c}{ Chlorophyll a } & \multicolumn{2}{c}{ Chlorophyll $\boldsymbol{b}$} & \multicolumn{2}{c}{$\beta$-carotene } & \multicolumn{2}{c}{ Violaxanthin } \\
\hline & \multicolumn{2}{c}{ Days } & \multicolumn{2}{c}{ Days } & \multicolumn{2}{c}{ Days } & \multicolumn{2}{c}{ Days } \\
\hline & 15 & 30 & 15 & 30 & 15 & 30 & 15 & 30 \\
\hline 0 & $6.455 \mathrm{a}$ & $3.18 \mathrm{a}$ & $1.66 \mathrm{a}$ & $0.909 \mathrm{a}$ & $0.62 \mathrm{ab}$ & $0.177 \mathrm{a}$ & $0.398 \mathrm{a}$ & $0.149 \mathrm{a}$ \\
\hline 20 & $4.766 \mathrm{~b}$ & $1.5 \mathrm{bc}$ & $2.3 \mathrm{a}$ & $0.466 \mathrm{~b}$ & $0.55 \mathrm{ab}$ & $0.129 \mathrm{ab}$ & $0.282 \mathrm{~b}$ & $0.063 \mathrm{~b}$ \\
\hline 40 & $6.143 \mathrm{ab}$ & $1.54 \mathrm{bc}$ & $1.64 \mathrm{a}$ & $0.479 \mathrm{ab}$ & $0.74 \mathrm{a}$ & $0.078 \mathrm{bc}$ & $0.372 \mathrm{ab}$ & $0.065 \mathrm{~b}$ \\
\hline 60 & $2.529 \mathrm{c}$ & $0.57 \mathrm{bc}$ & $0.75 \mathrm{~b}$ & $0.248 \mathrm{~b}$ & $0.25 \mathrm{bc}$ & $0.050 \mathrm{bc}$ & $0.143 \mathrm{c}$ & $0.02 \mathrm{~b}$ \\
\hline 80 & $2.27 \mathrm{c}$ & $0.09 \mathrm{c}$ & $0.77 \mathrm{~b}$ & $0.051 \mathrm{~b}$ & $0.24 \mathrm{bc}$ & $0.007 \mathrm{c}$ & $0.144 \mathrm{c}$ & $0.003 \mathrm{~b}$ \\
\hline 160 & $1.458 \mathrm{c}$ & $0.68 \mathrm{c}$ & $0.45 \mathrm{~b}$ & $0.224 \mathrm{~b}$ & $0.19 \mathrm{c}$ & $0.027 \mathrm{c}$ & $0.094 \mathrm{c}$ & $0.032 \mathrm{~b}$ \\
\hline
\end{tabular}


Chlorophyll b contents in plants exposed to $20 \mathrm{mM}$ levels of sodium chloride were similar to those observed in controls. Chlorophyll $b$ content fell significantly at higher sodium chloride concentrations after 15 days. Salt treatment significantly reduced chlorophyll $b$ at 30 days (Table 4). Plants presented necrosis at 30 days, and thus chlorophyll content was affected. In strawberry plants exposed to $0,8.55,17.10$, and $34.21 \mathrm{mM}$ of sodium chloride, total chlorophyll content did not change (Turhan and Eris, 2005), whereas in sweet cherry rootstock Gisela 5 (Prunus cerasus x Prunus canescens) a decrease in chlorophyll content was observed as a result of sodium chloride exposure $(0,50,100$, and $150 \mathrm{mM})$ (Erturk et al. 2007). Stoeva and Kaymakanova (2008) observed with beans that chlorophyll $a$, chlorophyll $b$, and carotenoids decreased with increasing salinity $(100 \mathrm{mM} \mathrm{NaCl})$.

At day $15, P$. fortunei plants grown at 80 and $160 \mathrm{mM}$ of sodium chloride had significantly diminished $\beta$-carotene content. After 30 days, this pigment significantly decreased in plants grown in sodium chloride at all concentrations tested (Table 4). At day 15 the violaxanthin content in the control was the same as that shown by plants that were grown in 20 and $40 \mathrm{mM}$ of sodium chloride. It significantly decreased in plants grown with increasing sodium chloride concentrations (Table 4).

\section{Proline determination}

In Paulownia imperialis, proline content significantly increased in plants exposed to increased sodium chloride levels. Plants grown in $40 \mathrm{mM}$ of sodium chloride showed the highest proline content. Proline accumulation in tissues of plants exposed to saline stress can be attributed to an increase in proline synthesis and a reduction in its degradation. With higher sodium chloride levels $(60,80$, and $160 \mathrm{mM})$ (Figure 1), a significant decline in proline content was observed. This is consistent with the experiments of Lutts et al. (2002) in rice cultivars that are sensitive to salt stress. In these experiments, proline content in leaves increased in plants exposed to $50 \mathrm{mM}$ of sodium chloride and decreased in plants exposed to $100 \mathrm{mM}$. Similar results were obtained in experiments made with Sapindus trifoliatus L. somatic embryo using different sodium chloride concentrations (Unnikrishnan et al. 1991). In our experiment proline content decrease could have been due to greater proline utilization than synthesis caused by $\mathrm{NaCl}$ stress.

In $P$. fortunei, proline content significantly decreased in plants grown at all sodium chloride concentrations, compared to controls. In particular, we observed less proline at the lowest salinity level $(20 \mathrm{mM})$ (Figure 2). This result agrees with data presented by Mademba et al. (2003) who suggest that proline accumulation helps to stabilise proteins at high ionic strength or at low water activity. In experiments conducted with sugar beets (Beta vulgaris L.) grown at different sodium chloride concentrations, similar results have been reported (Gzik, 1996). In Hordeum marinum and Hordeum vulgare, exposure to increasing sodium chloride concentrations also caused an increase in proline content (Garthwaite et al. 2005). Al-Khayri (2002) observed that in experiments on date palm callus a significant proline accumulation occurred when increasing sodium chloride $(0-225 \mathrm{mM})$. With Carrizo citrange proline increased with 30,60 , and $90 \mathrm{mM}$ of $\mathrm{NaCl}$ (Arbona et al. 2003).

Dracup (1991) mentioned that proline levels increase with increasing salt concentrations. This is consistent with our observations in $P$. imperialis grown in 
sodium chloride concentrations of $40 \mathrm{mM}$ or less. In $P$. fortunei, proline accumulation significantly decreased in plants grown in all sodium chloride concentrations (Figure 2 ). It is significant that this species is less tolerant to salinity than $P$. imperialis. Leaves of Suaeda physophora and stems of Haloxylon persicum grown with $300 \mathrm{mM}$ of sodium chloride did not show significant changes in proline content (Song et al. 2006). In this experiment, proline accumulation in plants grown with $40 \mathrm{mM}$ of sodium chloride may be due to the development of a stress tolerance mechanism to sodium chloride in $P$. imperialis. However, with increasing salt concentrations, proline content declined (Figure 1). Experiments with different varieties of sorghum (Sorghum bicolour) showed that proline was not associated with tolerance to saline stress (Caplan et al. 1990), whereas with rice (Oryza sativa L.), proline contributed to growth inhibition and a decline of chlorophyll levels in response to salinity (Garcia et al. 1997). In experiments with beans (Phaseolus vulgaris, L.), there was an increase in proline content with increasing salinity $(100 \mathrm{mM} \mathrm{NaCl})$ (Stoeva and Kaymakanova, 2008). In experiments with Citrus, it has been noted that the excess of sodium and chloride ions could act as inhibitors of proline response, and their accumulation could contribute to osmotic adjustment (Mademba et al. 2003). Proline content decline in plants exposed to higher salinity could be due to a greater use of proline by the plants. Both species of Paulownia responded differently to sodium chloride stress regarding proline accumulation.

Our results show that with increasing length of exposure to the sodium chloride levels used, pigment contents declined in both species. Activity inhibition of soluble proteins, proline, and lipid peroxidation, as well as the decrease in chlorophyll and carotenoids contents, indicate damage caused by sodium chloride at concentrations of $60 \mathrm{mM}$ and higher in $P$. imperialis and $P$. fortunei. The increased TBARS value shown by $P$. imperialis after 15 days may indicate lipid peroxidation of the cell membrane components caused by reactive oxygen species that are generated by oxidative stress. When oxidative stress is severe and prolonged, it can produce cell death, which was observed in this study in plants grown in higher levels of salinity with both species of Paulownia.

Table 4. Effect of sodium chloride $(\mathrm{mM})$ on pigments $(\mathrm{ng} / \mathrm{\mu g})$ in the aerial parts of Paulownia fortunei at 15 and 30 days. Letters denote a statistically significant difference $(P<$ 0.05 ) in levels of pigments at 15 and 30 days. Values not associated with the same letter are significantly different $(P<0.05)$.

\begin{tabular}{ccccccccc}
\hline $\begin{array}{c}\text { NaCl } \\
(\mathbf{m M})\end{array}$ & \multicolumn{2}{c}{ Chlorophyll $\boldsymbol{c}$} & \multicolumn{2}{c}{ Chlorophyll $\boldsymbol{b}$} & \multicolumn{2}{c}{$\beta$-carotene } & \multicolumn{2}{c}{ Violaxanthin } \\
\hline & \multicolumn{2}{c}{ Days } & \multicolumn{2}{c}{ Days } & \multicolumn{2}{c}{ Days } & \multicolumn{2}{c}{ Days } \\
\hline & 15 & 30 & 15 & 30 & 15 & 30 & 15 & 30 \\
\hline 0 & $6.455 a$ & $3.18 \mathrm{a}$ & $1.66 \mathrm{a}$ & $0.909 \mathrm{a}$ & $0.62 \mathrm{ab}$ & $0.177 \mathrm{a}$ & $0.398 \mathrm{a}$ & $0.149 \mathrm{a}$ \\
\hline 20 & $4.766 \mathrm{~b}$ & $1.5 \mathrm{bc}$ & $2.3 \mathrm{a}$ & $0.466 \mathrm{~b}$ & $0.55 \mathrm{ab}$ & $0.129 \mathrm{ab}$ & $0.282 \mathrm{~b}$ & $0.063 \mathrm{~b}$ \\
\hline 40 & $6.143 \mathrm{ab}$ & $1.54 \mathrm{bc}$ & $1.64 \mathrm{a}$ & $0.479 \mathrm{ab}$ & $0.74 \mathrm{a}$ & $0.078 \mathrm{bc}$ & $0.372 \mathrm{ab}$ & $0.065 \mathrm{~b}$ \\
\hline 60 & $2.529 \mathrm{c}$ & $0.57 \mathrm{bc}$ & $0.75 \mathrm{~b}$ & $0.248 \mathrm{~b}$ & $0.25 \mathrm{bc}$ & $0.050 \mathrm{bc}$ & $0.143 \mathrm{c}$ & $0.02 \mathrm{~b}$ \\
\hline 80 & $2.27 \mathrm{c}$ & $0.09 \mathrm{c}$ & $0.77 \mathrm{~b}$ & $0.051 \mathrm{~b}$ & $0.24 \mathrm{bc}$ & $0.007 \mathrm{c}$ & $0.144 \mathrm{c}$ & $0.003 \mathrm{~b}$ \\
\hline 160 & $1.458 \mathrm{c}$ & $0.68 \mathrm{c}$ & $0.45 \mathrm{~b}$ & $0.224 \mathrm{~b}$ & $0.19 \mathrm{c}$ & $0.027 \mathrm{c}$ & $0.094 \mathrm{c}$ & $0.032 \mathrm{~b}$ \\
\hline
\end{tabular}


$P$. imperialis is tolerant to sodium chloride at $40-60 \mathrm{mM}$ of sodium chloride concentrations. Further investigations are needed to determine the influence of sodium chloride on Paulownia species, in order to elucidate the mechanisms utilised by these species. With wheat it was found that the development stage is important for stress response (Shao et al. 2005b). The osmotic adjustment is the main component of the physiological machinery to which plants respond to water stress; it has been reported that with high proline and low MDA levels, wheat cultivars resisted better in drought conditions (Shao et al. 2006).

Probably stress-tolerant plants accumulate compatible solutes that will be generated in other species. For practical application in crop plants, the synthesis capacity for a particular solute must be consistent and improved. Increases in expression levels on plant and availability of substrate in a specific subcellular compartment must facilitate the generation of plants that produce high levels of certain compatible solutes and are thus tolerant to multiple stresses (Chen and Murata, 2002). Plant response to salinity varies with climate and growing conditions, crop management and irrigation, variety, and sensitivity of the crops in different growth stages (Chartzoulakis, 2005).

During plant growth in desert areas, there are important conditions which limit the factors that influence plant growth and development and affect production and quality, as drought and salinity (Shao and Chu, 2005). In all life processes a mutual relationship between plant response and the environment is very important and is the essential basis for different types of sustainable development in the world, particularly for sustainable agricultural development.

In other studies (Ayala-Astorga et al. 2009) with both Paulownia species grown in vitro, it was reported they survived at a $\mathrm{NaCl}$ concentration of $60 \mathrm{mM}$, and that higher concentrations induced necroses and death. These results indicate that both species are slightly tolerant to sodium salinity. It has also been reported that $P$. imperialis was more resistant than $P$. fortunei in studies of physiological variables under drought conditions with both species of Paulownia growing at pots and in the field (LlanoSotelo et al. 2010).

Zhang et al. (2009) suggested that it was important to understand molecular mechanisms involving stress perception, signal transduction, and transcriptional stress tolerance regulation, which could help engineer tolerance to multiple stresses in crop plants. They also mentioned that advances in the molecular biology of stress responses in tolerant organisms introduce the potentials of stress tolerance genes in agricultural programmes, not only to ensure survival but also to ensure productivity.

Despite advances in understanding tolerance and achievement mechanisms in plants, there are still important issues to consider and study in the future, such as the effect of the expression in other crops, the impact on ecosystem productivity, and so on for a realistic agronomic assessment. However, a comprehensive and accurate view held about the problem and methods that are currently available for deepening the study as a complex phenomenon have changed the outlook and have opened up many more possibilities for improving crop tolerance to salinity.

In general there is much work to do to improve crops because the problem is increasing with salinity, drought, and other worldwide factors that affect crops. We are considering expanding our research on Paulownia since it is an important woody 
species in reforestation programmes, which can diminish desertification and will be an intercropping species.

\section{ACKNOWLEDGMENTS}

We express thanks to José Llano Sotelo from Departamento de Investigaciones Científicas y Tecnológicas de la Universidad de Sonora (DICTUS), Amparo Nieblas and Francisco Vásquez from Centro de Investigaciones en Alimentos y Desarrollo (CIAD), Hermosillo, Sonora and Sergio Real Cosío from CIBNOR for technical assistance and to Departamento de Investigaciones Científicas y Tecnológicas (DICTUS).

\section{REFERENCES}

AKINCI, Irfan Ersin and SIMSEK, Murat. Ameliorative effects of potassium and calcium on the salinity stress in embryo culture of cucumber (Cucumis sativus L.). Journal of Biological Sciences, May-June 2004, vol. 4, no. 3, p. 361-365. [CrossRef]

AL-KHAYRI, Jameel M. Growth proline accumulation, and ion content in sodium chloridestressed callus of date palm. In vitro Cellular and Development Biology-Plant, January 2002, vol. 38, no. 1, p. 79-82. [CrossRef]

ARBONA, Vicent; FLORS, Víctor; JACAS, Josep; GARCÍA-AGUSTíN, Pilar and GOMEZCADENAS, Aurelio. Enzimatic and non-enzimatic antioxidant responses of carrizo citrange, a salt-sensitive citrus roostoock, to different levels of salinity. Plant Cell Physiology, April 2003, vol. 44, no. 4, p. 388-394. [CrossRef]

AYALA-ASTORGA, Gloria Irma; ALCARAZ-MELÉNDEZ, Lilia; AYALA, P. Francisco and CASTELLANOS, Alejandro Emilio. Effect of sodium chloride stress in Paulownia imperialis (Siebold \& Zaccarini) and Paulownia fortunei (Seemann \& Hemsley) plant growing in vitro. Agrochimica, March-April 2009, vol. 53, no. 2, p. 65-78.

BARTELS, Dorothea and SUNKAR, Ramanjulu. Drought and salt tolerance in plants. Critical Review in Plants Science, February 2005, vol. 24, no. 1, p. 23-58. [CrossRef]

BENAVIDES, Adalberto. Ecofisiología y Bioquímica del estrés en plantas. Universidad Autónoma Agraria Antonio Narro. Departamento de Horticultura, Buenavista, Saltillo, Coah. México, 2002. 89 p. ISBN 968-844-042-6.

BERGMANN, Ben A. Propagation method influences first year field survival and growth of Paulownia. New Forests, November 1998, vol. 16, no. 3, p. 251-264. [CrossRef]

BERGMANN, Ben A. Five years of Paulownia field trials in North Carolina. New Forests, May 2003, vol. 25, no. 3, p. 185-199. [CrossRef]

BONNER, F.T. Paulownia tomentosa (Thunb.) Sieb. \& Zucc. Ex Steud, royal Paulownia. In: BURNS, R.M. and HONCALA, B.H. eds. Silvics of North America, vol. 2, Hardwoods Agric Handbk 654 Washington DC, USDA Forest Service, 1995, p. 501-502.

BRADFORD, Marion M. A rapid and sensitive method for the quantitation of microgram quantities of protein utilizing the principle of protein-dye binding. Analitical Biochemistry, May 1976, vol. 72, no. 1-2, p. 248-254. [CrossRef]

CAPLAN, A.B.; DEKEYSER, C.R. and VAN MONTAGU, M. Salinity and drought stress in rice. In: SANGWAN, R.S. and SANGWAN-NORREL, B. eds. The Impact of Biotechnology in Agriculture. Kluwer Academic Publishers The Netherlands, 1990, p. 391-402.

CAVAGNARO, Juan B.; PONCE, María T.; GUZMAN, Javier and CIRRINCIONE, Miguel A. Argentinean of cultivars of Vitis vinifera grow better than European ones when cultured in vitro under salinity. Biocell, January-April 2006, vol. 30, no. 1, p. 1-7.

CAVALCANTI, Fabio Rossi; ABREU-OLIVEIRA, José Tadeu; MARTINS-MIRANDA, Aparecida Simone; ALMEIDA-VIEGAS, Ricardo and GOMES-SILVEIRA, Joaquín Albenísio. Superoxide dismutase, catalase and peroxidase activities do not confer protection against oxidative damage in salt-stressed cowpea leaves. New Phytologist, September 2004, vol. 163, no. 3, p. 563-571. [CrossRef] 
CHARTZOULAKIS, Kostas. Salinity and olive: Growth, salt tolerance, photosynthesis and yield. Agricultural Water Management, September 2005, vol. 78, no. 1-2, p. 108-121. [CrossRef]

CHINNUSAMY, Viswanathan; JAGENDORF, André and ZHU, Jian-Kang. Understanding and improving salt tolerance in plants. Crop Science, March-April 2005, vol. 45, p. 437-448

CHEN, Tony H.H. and MURATA, Norio. Enhancement of tolerance of abiotic stress by metabolic engineering of betaines and other compatible solutes. Current Opinion in Plant Biology, June 2002, vol. 5, no. 3, p. 250-257. [CrossRef]

CHEN, Zhonghua; CUIN, Tracey A.; ZHOU, Meixue; TWOMEY, Amanda; NAIDU, Bodapati P. and SHABALA, Sergey. Compatible solute accumulation and stress-mitigating effects in barley genotypes contrasting in their salt tolerance. Journal of Experimental Botany, December 2007, vol. 58, no. 15-16, p. 4245-4255. [CrossRef]

CUSHMAN, John C. Osmoregulation in plants: Implications for agriculture. American Zoologist, August 2001, vol. 41, no. 4, p. 758-769. [CrossRef]

DI MARTINO, Catello; SEBASTIANO, Delfine; PIZZUTO, Roberto; LORETO, Francesco and FUGGI, Amodio. Free amino acid and glycine betaine in leaf osmoregulation of spinach responding to increasing salt stress. New Phytologist, June 2003, vol. 158, no. 3, p. 455463. [CrossRef]

DRACUP, M. Increasing salt tolerance of plants through cell culture requires greater understanding of tolerance mechanisms. Australian Journal Plant Physiology, February 1991, vol. 18, no. 1, p. 1-15. [CrossRef]

EL-BAKY, A.; HANAA, H.; AMAL, A. and HUSSEIN, M.M. Influence of salinity on lipid peroxidation, antioxidant enzymes and electrophoretic patterns of protein and isoenzymes in leaves of some onion cultivars. Asian Journal of Plant Sciences, 2003, vol. 2, no. 8, p. 633-638. [CrossRef]

ERTURK, U.; SIVRITEPE, N.; YERLIKAYA, C.; BOR, M.; OZDEMIR, F. and TURKAN, I. Response of the cherry rootstock to salinity in vitro. Biologia Plantarum, September 2007, vol. 51, no. 3, p. 597-600. [CrossRef]

ESFANDIARI, Ezatollah; SHEKARI, Fariborz; SHEKARI, Farid and ESFANDIARI, Manouchehr. The effect of salt stress on antioxidant enzymes activity and lipid peroxidation on the wheat seedling. Notulae Botanicae Horti Agrobotanici Cluj-Napoca, October 2007, vol. 35, no. 1, p. 48-56.

FRANCO, O.L.; FILHO, J.E.; PRISCO, J.T. and FILHO, E.G. Effects of $\mathrm{CaCl} 2$ on growth and osmoregulator accumulation in $\mathrm{NaCl}$ stressed cowpea seedlings. Revista Brasileira de Fisiología Vegetal, December 1999, vol. 11, no. 3, p. 145-151.

GARTHWAITE, Alaina; VON BOTHMER, Roland J. and COLMER, Timothy D. Salt tolerance in wild Hordeum species is associated with restricted entry of $\mathrm{Na}^{+}$and $\mathrm{Cl}^{-}$into the shoots. Journal of Experimental Botany, July 2005, vol. 56, no. 419, p. 2365-2378. [CrossRef]

GARCIA, Ana B.; ENGLER, A. Janice; IYER, Suresh; GERATS, Tom; VAN MONTAGU, Marc and CAPLAN, Allan B. Effects of osmoprotectant upon $\mathrm{NaCl}$ stress in rice. Plant Physiology, September 1997, vol. 115, no. 1, p. 159-169.

GZIK, A. Accumulation of proline and pattern of $\alpha$-amino acids in sugar beet plants in response to osmotic, water and salt stress. Enviromental and Experimental Botany, May 1996, vol. 36, no. 1, p. 29-38. [CrossRef]

JIANBO, Lu. Energy balance and economic benefits of two agroforestry systems in northern and southern China. Agriculture, Ecosystems and Environment, September 2006, vol. 116, no. 3-4, p. 255-262. [CrossRef]

KOCA, Hulusi; BOR, Melike; ÖZDEMIR, Filiz and TÜRKAN, Ismail. The effect of salt stress on lipid peroxidation, antioxidative enzymes and proline content of sesame cultivars. Enviromental and Experimental Botany, July 2007, vol. 60, no. 3, p. 344-351. [CrossRef]

LUTTS, S.; MAJERUS, V. and KINET, J.M. NaCl effects on proline metabolism in rice (Oriza sativa) seedlings. Physiologia Plantarum, March 1999, vol. 105, no. 3, p. 450458. [CrossRef]

LLANO-SOTELO, José Manuel; ALCARAZ-MELÉNDEZ, Lilia and CASTELLANOS VILLEGAS, Alejandro. Gas exchange in Paulownia species growing under different soil moisture conditions in the field. Journal Environmental Biology, July 2010, vol. 31, no. 4, p. 497502.

MADEMBA, F.; BOUCHEREA, U.A. and LARHER, F.R. Proline accumulation in cultivated citrus and its relationship with salt tolerance. Journal of Horticultural Science \& Biotechnology, September 2003, vol. 78, no. 5, p. 617-623. 
MUTHURI, C.W.; ONG, C.K ; BLACK, C.R.; NGUMI V.W. and MATI, B.M. Tree and crop productivity in Grevillea, Alnus and Paulownia-based agroforestry systems in semi-arid Kenya. Forest Ecology and Management, July 2005, vol. 212, no. 1-3, p. 2339. [CrossRef]

OMAR, Mobashar S.; YOUSIF, Dheya P.; AL-JIBOURI, Abdel-Jassim M.; AL-RAWI, Maha S. and HAMEED, Mohammed K. Effects of gamma rays and sodium chloride on growth and cellular constituents of sunflower (Helianthus annuus L.) callus cultures. Journal of Islamic Academic of Science, January 1993, vol. 6, no. 1, p. 69-72.

PERSKY, Adam M.; GREEN, Pattie S.; STUBLEY, Leighann; HOWELL, Cynthia O.; ZAULYANOV, Larissa; BRZAEAU, Gayle A. and SIMPKINS, James W. Protective effect of estrogen against oxidative damage to heart and skeletal muscle in vivo and in vitro. Proceedings of the Society of Experimental Biology and Medicine, January 2000, vol. 223, no. 1, p. 59-66.

QIU, Nianwei; LU, Quingtao and LU, Congming. Photosynthesis, photosystem II efficiency and the xanthophylls cycle in the salt adapted halophyte Atriplex centralasiatica. New Phytologist, August 2003, vol. 159, no. 2, p. 479-486. [CrossRef]

RATHINASABAPATHI, Bala. Metabolic engineering for stress tolerance: Installing osmoprotectant synthesis pathways. Annals of Botany, October 2000, vol. 86, no. 4, p. 709-716. [CrossRef]

SCHLEIFF, U. Analysis of water supply of plants under saline soil conditions and conclusions for research on crop salt tolerance. Journal of Agronomy and Crop Science, February 2008, vol. 194, no. 1, p. 1-8. [CrossRef]

SHAO, Hong-Bo and CHU, Li-Ye. Plant molecular biology in China: opportunities and challenges. Plant Molecular Biology Reporter, December 2005, vol. 23, no. 4, p. 345358. [CrossRef]

SHAO, Hong-Bo; LIANG, Zong Suo; SHAO, Ming An and SUN, Qun. Dynamic changes of antioxidative enzymes of 10 wheat genotypes at soil water deficits. Colloids and Surfaces B: Biointerfaces, May 2005a, vol. 42, no. 3-4, p. 187-195. [CrossRef]

SHAO, Hong-Bo; LIANG, Zong Suo; SHAO, Ming-An; SUN, Shi Meng and HU, Zan Mind. Investigation on dynamic changes of photoshynthetic characteristics of 10 wheat (Triticum aestivum L.) genotypes during two vegetative -growth stages at water deficits. Colloids and surfaces B: Biointerfaces, July 2005b, vol. 43, no. 3-4, p. 221-227. [CrossRef]

SHAO, Hong-Bo; LIANG, Zong Suo and SHAO, Ming-An. Osmotic regulation of 10 wheat (Triticum aestivum L.) genotypes at soil water deficits. Colloids and surfaces $B$ : Biointerfaces, February 2006, vol. 47, no. 2, p. 132-139. [CrossRef]

SHAO, Hong-Bo; GUO, Quin-Jie; CHU, Li-Ye; ZHAO, Xi-Ning; SU, Zhong-Liang; HU, Ya-Cheng and CHENG, Jiang-Feng. Understanding molecular mechanism of higher plant plasticity under abiotic stress. Colloids and Surfaces B: Biointerfaces, January 2007a, vol. 54, no. 1, p. 37-45. [CrossRef]

SHAO, Hong-Bo; JIANG, Shui-Yuan; LI, Feng-Mei; CHU, Li-Ye; ZHAO, Chang-Xing; SHAO, Ming-An; ZHAO, Xi-Ning and LI, Feng. Some advances in plant stress physiology and their implication in the system biology era. Colloids and surfaces B: Biointerfaces, January 2007b, vol. 54, no.1, p. 33-36. [CrossRef]

SHAO, Hong-Bo; CHU, Li-Ye and SHAO, Ming-An. Calcium as a versatile plant signal transducer under soil water stress. BioEssays, July 2008, vol. 30, no. 7, p. 634641. [CrossRef]

SIVRITEPE, N. and ERIS, A. Determination of salt tolerance in some grapevine cultivars (Vitis vinifera L.) under in vitro conditions. Turkish Journal of Biology, November 1999, vol. 23, no. 4 , p. 473-485

SONG, Jie; DING, Xiaodong; FENG, Gu and ZHANG, Fusuo. Nutritional and osmotic roles of nitrate in a euhalophyte and a xerophyte in saline conditions. New Phytologist, July 2006, vol. 171, no. 2, p. 357-366. [CrossRef]

SONG, Wei-Yi; ZHANG, Zheng-Bin; SHAO, Hong-Bo; GUO, Xiu-Lin; CAO, Hong-Xing; ZHAO, Hong-Bin; FU, Zheng-Yan and HU, Xiao-Jun. Relationship between calcium decoding elements and plant abiotic-stress resistance. International Journal of Biological Sciences, April 2008, vol. 4, no. 2, p. 116-125.

STOEVA, Nevena and KAYMAKANOVA, Miroslava. Effect of salt stress on the growth and photosynthesis rate of bean plants (Phaseolus vulgaris L.). Journal Central Europan Agriculture, October 2008, vol. 9, no. 3, p. 385-392. 
TABATABAEI, S.J. Effects of salinity and $\mathrm{N}$ on the growth, photosynthesis and $\mathrm{N}$ status of olive (Olea europaea L.) trees. Scientia Horticulturae, May 2006, vol. 108, no. 4, p. 432438. [CrossRef]

TESTER, Mark and DAVENPORT, Romola. $\mathrm{Na}+$ Tolerance and $\mathrm{Na}+$ transport in higher plants. Annals of Botany, February 2003, vol. 91, no. 5, p. 503-527. [CrossRef]

TRIGIANO, Robert N. and GRAY, Dennis J. Plant tissue culture: concepts and laboratory exercise. Second edition. Florida CRC Press LLC. 2000. 454 p. ISBN 9780849320293.

TURHAN, Ece and ERIS, Atilla. Changes of micronutrients, dry weight and chlorophyll contents in strawberry plants under salt stress conditions. Communications in Soil Science and Plant Analysis, April 2005, vol. 36, no. 7-8, p. 1021-1028. [CrossRef]

UNNIKRISHNAN, S.K.; PRAKASH, L.; JOSEKUTTY, P.C. and MEHTA, A.R. Effect of $\mathrm{NaCl}$ salinity on somatic embryo development in Sapindus trifoliatus L. Journal Experimental Botany, March 1991, vol. 42, no. 3, p. 401-406. [CrossRef]

VAZQUEZ-ORTíZ, F.A.; CAIRE, G.; HIGUERA-CIAPARA, I. and HERNANDEZ, G. High performance liquid chromatographic determination of free amino acids in shrimp. Journal of Liquid Chromatography and Related Technologies, June 1995, vol. 18, no. 10, p. 20592068. [CrossRef]

VIDUSSI, Francesca; CLAUSTRE, Hervé; BUSTILLOS-GUZMAN, José; CAILLIAU, Caroline and MARTY, Jean-Claude. Determination of chlorophylls and carotenoids of marine phytoplankton: separation of chlorophyll a from divinyl-chlorophyll $a$ and zeaxanthin from lutein. Journal of Plankton Research, December 1996, vol. 18, no. 12, p. 23772382. [CrossRef]

VIEIRA-SANTOS, C.; CAMPOS, A.; AZEVEDO, H. and CALDEIRA, G. In situ and in vitro senescencia induced by $\mathrm{KCl}$ stress: nutricional imbalance, lipid peroxidation and antioxidant metabolism. Journal of Experimental Botany, February 2001, vol. 52, no. 355, p. 351-360. [CrossRef]

VINOCUR, Basia and ALTMAN, Arie. Recent advances in engineering plant tolerance to abiotic stress: achievements and limitations. Current Opinion in Biotechnology, April 2005, vol. 16, no. 2, p. 123-132. [CrossRef]

WANG, Wangxia; VINOCUR, Basia and ALTMAN, Arie. Plant responses to drought, salinity and extreme temperatures: toward genetic engineering for stress tolerance. Planta, November 2003, vol. 218, no. 1, p. 1-14. [CrossRef]

WANICHANANAN, Praderm; KIRDMANEE, Chalermpol and VUTIYANO, Chawewan. Effect of salinity on biochemical and physiological characteristic in correlation to selection on salttolerance in aromatic rice (Oryza sativa L.). Science Asia, December 2003, vol. 29, no. 4, p. 333-339. [CrossRef]

ZHANG, Zhengbin; SHAO, Hongbo; XU, Ping; HU, Mengyun; SONG, Weiyi and HU, Xiaojun. Focus on agricultural biotechnology: Prospective for bio-watersaving theories and their applications in the semi-arid and arid areas. African Journal of Biotechnology, June 2009, vol. 8 , no. 12 , p. $2779-2789$.

\section{How to cite this article:}

AYALA-ASTORGA, G.I. and ALCARAZ-MELÉNDEZ, L. Salinity effects on protein content, lipid peroxidation, pigments, and proline in Paulownia imperialis (Siebold \& Zuccarini) and Paulownia fortunei (Seemann \& Hemsley) grown in vitro. Electronic Journal of Biotechnology, September 2010, vol. 13, no. 5. http://dx.doi.org/10.2225/vol13-issue5-fulltext-13 